\title{
STRATEGI PENGEMBANGAN OBJEK WISATA DANAU LINOUW TERHADAP PENINGKATAN PENDAPATAN ASLI DAERAH (PAD) KOTA TOMOHON
}

\author{
Ireyne Olivia Eman \\ Benny Adrian Berthy Sagay \\ Sherly Gladys Jocom
}

\begin{abstract}
The purpose of this study are to know about strategys to development tourism object Danau Linouw to increasing local revenue of Tomohon City. This study use descriptive qualitative method. The sampling technique is taken based on the consideration that the existing population is not known exactly in number so using accidental sampling. The variables in this study consisted of the development of tourist attraction and the increase of local revenue (PAD). Data collection techniques consist of interviews, observation, questionnaires, documentation. Data analysis techniques use SWOT analysis and development strategy. The result of the research shows that the development strategy of Lake Linouw Tourism Object in increasing Tomohon District Revenue (PAD) based on SWOT analysis has been done, located in Quadrant I position or strategy through Horizontal Integration, which is located between external opportunity and internal strength. This is a major strategy for developing tourism by maintaining strength and optimizing opportunities while improving weaknesses and anticipating existing threats in an effort to increase the number of tourist arrivals that can increase local revenue (PAD) of Tomohon City. To increase the original revenue of Tomohon City, it is hoped that the Government and Private sector, especially Lake Linouw Tourism Manager, need to plan a marketing strategy so that tourists who visit will continue to grow. Improving facilities and infrastructure related to access road to Lake Linouw attraction which is considered less extensive to be passed by visitors who use motor vehicles.
\end{abstract}

Keywords: Strategy, Tourism Development, Increasing Local Revenue (PAD), Tomohon City.

\begin{abstract}
ABSTRAK
Penelitian ini bertujuan untuk mengetahui strategi - strategi untuk pengembangan objek wisata Danau Linouw untuk peningkatan PAD Kota Tomohon. Jenis penelitian menggunakan metode deskriptif kualitatif. Teknik pengambilan sampel diambil berdasarkan pertimbangan bahwa populasi yang ada tidak diketahui secara pasti jumlahnya sehingga menggunakan accidental sampling. Variabel dalam penelitian ini terdiri dari pengembangan objek wisata dan peningkatan pendapatan asli daerah (PAD). Teknik pengumpulan data terdiri dari wawancara, observasi,kuesioner, dokumentasi. Teknik analisa data menggunakan analisis SWOT dan strategi pengembangan. Hasil penelitian menunjukkan bahwa strategi pengembangan Obyek Wisata Danau Linouw dalam meningkatkan Pendapatan Asli Daerah (PAD) Kota Tomohon berdasarkan hasil analisis SWOT yang telah dilakukan, terletak pada posisi Kuadran I atau strategi melalui Integrasi Horizontal, yang terletak antara peluang eksternal dan kekuatan internal. Hal ini merupakan strategi utama untuk mengembangkan obyek wisata dengan cara mempertahankan kekuatan dan mengoptimalkan peluang sambil memperbaiki kelemahan dan mengantisipasi ancaman yang ada dalam upaya meningkatkan jumlah kunjungan wisatawan yang dapat meningkatkan Pendapatan Asli Daerah (PAD) Kota Tomohon.Untuk meningkatkan Pendapatan Asli Daerah Kota Tomohon, maka diharapkan Pemerintah dan Swasta khususnya pengelola Obyek Wisata Danau Linouw perlu merencanakan sebuah strategi pemasaran agar wisatawan yang berkunjung akan terus bertambah. Memperbaiki sarana dan prasarana terkait jalan akses menuju obyek wisata Danau Linouw yang dinilai kurang luas untuk dilewati pengunjung yang menggunakan kendaraan bermotor.
\end{abstract}

Kata kunci : Strategi, Pengembangan Objek Wisata, PAD, Kota Tomohon. 


\section{PENDAHULUAN}

\section{Latar Belakang}

Pembangunan di Indonesia sedang mengalami perkembangan yang signifikan. Hal ini dapat dilihat dari pembangunan pembangunan infrastruktur yang dilakukan oleh pemerintah pusat yang berkoordinasi dengan pemerintah di daerah untuk merealisasikan pembangunan yang telah direncanakan. Pemusatan pembangunan ekonomi wilayah menjadi prioritas pemerintah daerah. Disisi lain dalam pandangan pembangunan ekonomi wilayah menyatakan bahwa pembangunan merupakan pertambahan pendapatan masyarakat secara keseluruhan yang terjadi di wilayah tersebut, yaitu kenaikan seluruh nilai tambah (added value) yang terjadi(Tarigan, 2006).

Pembangunan bukan semata-mata merupakan fenomena ekonomi. Dalam pengertian yang paling mendasar, pembangunan haruslah mencakup masalah materi dan finansial dalam kehidupan manusia. Oleh karena itu pembangunan seharusnya diselidiki sebagai suatu proses multidimensional yang melibatkan reorganisasi dan reorientasi dari semua sistem ekonomi dan sosial (Todaro, 2000).

Republik Indonesia merupakan suatu negara yang memiliki berbagai macam suku dan budaya terlebih sumber daya alam yang sangat banyak dan luas. Dengan kekayaan alam yang dimiliki terlebih dari sumber daya alam yang tersedia, tentunya sangat mudah bagi Indonesia untuk meningkatkan pertumbuhan ekonomi bagi masyarakat. Hal tersebut tentunya didukung dengan pengelolaan kekayaan sumber daya alam yang tersedia yang dikelola dengan baik, baik dari sektor swasta ataupun pemerintah.

Dengan adanya peraturan otonomi daerah sebagaimana yang tertuang dalam Undangundang Nomor 22 Tahun 1999 yang kemudian diubah menjadi Undang-Undang Nomor 32 Tahun 2004 tentang Pemerintahan Daerah, disebutkan bahwa pemerintah daerah berwenang untuk mengatur dan mengurus sendiri urusan pemerintahan menurut asas yang berlaku dan tugas pembantuan. Pemberian wewenang pemerintah pusat kepada daerah diarahkan untuk mempercepat terjadinya perubahan guna mencapai kesejahteraan masyarakat melalui kualitas pelayanan yang juga melibatkan peran serta masyarakat. Melalui undang - undang otonomi daerah, memberikan kesempatan bagi masing - masing daerah untuk mengatur kebijakan - kebijakan sendiri sesuai dengan kewenangan yang diberikan dari pemerintah pusat kepada pemerintah daerah.

Dengan otonomi daerah, setiap daerah dapat menggali potensi yang bisa dikembangkan, sehingga perkembangan masing-masing daerah dapat meningkat pesat. Terdapat berbagai sektor yang dapat dikembangkan, diantaranya adalah: sektor perdagangan, sektor jasa, sektor pertanian, sektor pariwisata dan lain-lain (Nurhadi dkk, 2013). Tetapi masalah pokok dalam pembangunan ekonomi daerah adalah terletak pada penekanan terhadap kebijakan-kebijakan pembangunan yang didasarkan pada kekhasan daerah yang bersangkutan (endogenous development) dengan menggunakan potensi sumber daya manusia, kelembagaan, dan sumber daya fisik secara local (Badrudin, 2012;4).

Salah satu yang menjadi andalan untuk pembangunan ekonomi daerah berasal dari bidang pariwisata. Pariwisata merupakan sebuah aktivitas yang menyentuh dan melibatkan masyarakat baik secara langsung maupun tidak langsung. Pariwisata mampu membuat masyarakat setempat mengalami perubahan pada kehidupan dalam aspek sosial, ekonomi, budaya, lingkungan, ilmu pengetahuan maupun terbukanya lapangan pekerjaan. Aspek-aspek tersebut merupakan potensi positif melalui pemanfaatan sumber daya alam yang ada pada sebuah daerah untuk mengembangkan obyek pariwisata.

Peranan pariwisata dalam pembangunan ekonomi diberbagai negara tidak diragukan lagi. Banyak negara mengembangkan potensi pariwisata dengan serius karena pariwisata bisa mendatangkan devisa bagi negara, pengurangan angka pengangguran sertapengentasan kemiskinan. Pariwisata sangat layak untuk dipandang sebagai objek kajian dan 
dikembangkan sebagai ilmu, karena mempunyai sejarah, pustaka, dan prinsip-prinsip yang terstruktur serta berbagai aspek keilmuan lainnya (Pitana dan Diarta, 2009).

Sebuah obyek pariwisata dapat dikembangkan sebagai salah satu sektor andalan guna mendorong pertumbuhan ekonomi, meningkatan pendapatan daerah, pemberdayaan perekonomian masyarakat, memperluas lapangan kerja dan kesempatan berusaha, serta meningkatkan pengenalan dan pemasaran produk dalam rangka meningkatkan kesejahteraan masyarakat. Namun dalam melakukan pengembangan sebuah objek wisata harus terencana secara komprehensif, sehingga manfaatnya dapat diperoleh bagi masyarakat.

Objek wisata adalah suatu tempat yang menjadi kunjungan wisatawan karena mempunyai sumberdaya tarik, baik alamiah, maupun buatan manusia, seperti keindahan alam atau pegunungan, pantai flora dan fauna, kebun binatang, bangunan kuno bersejarah, monumenmonumen, candi-candi, tari-tarian, atraksi dan kebudayaan khas lainnya (Adisasmita, 2010) sedangkan menurut Fandeli (2000), objek wisata adalah perwujudan daripada ciptaan manusia, tata hidup, seni budaya serta sejarah bangsa dan tempat atau keadaan alam yang mempunyai daya tarik untuk dikunjungi wisatawan. Sedangkan objek wisata alam adalah objek wisata yang daya tariknya bersumber pada keindahan sumber daya alam dan tata lingkungannya.

Pengembangan objek wisata berkaitan erat dengan pelestarian nilai-nilai kepribadian dan pengembangan budaya bangsa, dengan memanfaatkan seluruh potensi keindahan dan kekayaan alam. Pemanfaatan disini bukan berarti merubah secara total, tetapi mengelola, memanfaatkan dan melestarikan setiap potensi yang ada, dimana potensi tersebut dirangkaikan menjadi satu daya tarik wisata. Oleh karena itu pengelolaan dan memanfaatkan potensi pariwisata yang dimiliki daerah juga dikelola oleh masing-masing daerah. Sektor pariwisata sangat dimungkinkan karena ketersediaan berbagai potensi pariwisata yang ada serta dukungan pemerintah daerah dalam bentuk regulasi. Pengelolaan objek pariwisata yang berada di daerah dan terlebih dikelolah dengan baik, dampak positif untuk menunjang pembangunan dari sektor pariwisata dimana pengembangan sektor pariwisata merupakan salah satu upaya yang dapat meningkatkan pendapatan asli daerah (PAD).

Pendapatan Asli Daerah (PAD) merupakan semua penerimaan yang diperoleh daerah dari sumber-sumber dalam wilayahnya sendiri yang dipungut berdasarkan peraturan daerah sesuai dengan peraturan perundangundangan yang berlaku (Halim, 2004:96). Sektor pendapatan daerah memegang peranan yang sangat penting, karena melalui sektor ini dapat dilihat sejauh mana suatu daerah dapat membiayai kegiatan pemerintah dan pembangunan daerah. Berdasarkan UndangUndang Nomor 33 Tahun 2004 Pasal 3, PAD bertujuan memberikan kewenangan kepada pemerintah daerah untuk mendanai pelaksanaan otonomi daerah sesuai dengan potensi daerah sebagai perwujudan desentralisasi.

Dengan adanya kebijakan dari pemerintah pusat untuk pengelolaan pembangunan di daerah masing - masing di seluruh Indonesia termasuk di sektor pariwisata, masing - masing daerah diharapkan agar mampu mengolah sumber daya yang tersedia baik sumber daya manusia maupun sumber daya alam yang nantinya dapat memberi pengaruh pada PAD. Perkembangan sebuah kawasan wisata dapat memberikan hal positif bagi pemerintah daerah. Salah satunya ialah untuk peningkatan Pendapatan Asli Daerah (PAD). Faktor-faktor yang mempengaruhi peningkatan PAD dari sektor pariwisata dapat bersumber dari:

(a) Retribusi objek wisata,

(b) Tingkat hunian hotel;

(c) Pendapatan perkapita yang merupakan salah satu indikator yang penting untuk mengetahui kondisi ekonomi di suatu wilayah dalam periode tertentu yang di tunjukkan dengan Pendapatan Domestik Regional Bruto (PDRB) baik atas dasar harga berlaku maupun atas dasar harga konstan.

PAD dari sektor pariwisata lainnya dapat diperoleh juga dari pajak hotel, pajak restoran, pajak hiburan. Tercapainya target pendapatan dari pajak sektor pariwisata dari sebuah daerah, pada dasarnya lebih disebabkan oleh meningkatnya jumlah kunjungan wisatawan ke sebuah kawasan wisata.

Agrisosioekonomi:

Jurnal Transdisiplin Pertanian (Budidaya Tanaman, Perkebunan, Kehutanan, Peternakan, Perikanan), Sosial dan Ekonomi 
Salah satu daerah yang memiliki wilayah atau kawasan pariwisata yang menaerik yang memiliki banyak potensi pariwisata berada di provinsi Sulawesi Utara. Sulawesi Utara merupakan daerah yang memiliki objek-objek pariwisata yang tersebar di Kabupaten/Kota. Salah satu objek wisata yang sedang dikembangkan di Sulawesi Utara salah satunya objek wisata Danau Linouw yang berada di Kota Tomohon. Danau Linouw menjadi salah satu daya tarik wisata yang digemari oleh wisatawan mancanegara maupun nasional. Data kunjungan wisatawan yang berkunjung di berbagai objek wisata Kota Tomohon, menunjukkan bahwa Danau Linouw dijadikan sebagai tujuan yang paling favorit bagi wisatawan mancanegara maupun nasional. Danau Linouw menjadi destinasi wisata bagi wisatawan yang datang ke Kota Tomohon.

Berdasarkan data Dinas Pariwisata Kota Tomohon 2014, tercatat Danau Linouw telah dikunjungi oleh 7.304 wisatawan mancanegara dan 14.031 wisatawan nusantara selanjutnya objek wisata Gunung Mahawu yang dikunjungi oleh 4.434 wisatawan mancanegara dan 10.516 wisatawan nusantara, kemudian Bukit Doa Mahawu yang sudah dikunjungi sebanyak 2.227 wisatawan mancanegara dan 88.239 wisatawan nusantara serta beberapa objek wisata di Kota Tomohon yang dikunjungi oleh wisatawan meskipun jumlah kunjungannya kurang dominan dibandingkan dengan Danau Linouw.

Danau Linouw merupakan sebuah objek wisata yang memiliki keunikan yang secara alami, di antaranya perubahan tiga warna air danau, lumpur panas, belerang, dan memiliki satwa endemic berupa burung blibis dan serangga yang oleh penduduk setempat dinamakan "sayok" atau "komo". Perubahan warna air danau tersebut terjadi secara serentak dari warna hijau, biru muda, dan kecoklat-coklatan, bahkan kadang muncul pula warna seperti violet kehijauan. Perbuahan warna air Danau disebabkan karena adanya lumpur panas dan belerang yang ada di dasar danau, sedangkan belerang dan lumpur panas tersebut terjadi akibat dari gerakan vulkanik (magma) yang masih aktif di bawah perut bumi. Danau Linouw dapat menjadi tujuan pariwisata yang lebih unggul apabila terus dikembangkan yang bertujuan untuk meningkatkan daya tarik wisatawan yang meningkatkan kunjungan wisatawan.
Berkembangnya pariwisata di suatu daerah mendatangkan banyak manfaat bagi pemerintah daerah dan masyarakat, yakni secara ekonomi, sosial dan budaya. Namun, jika pengembangannya tidak dipersiapkan dan dikelola dengan baik, apalagi tanpa adanya peran masyarakat dan pemerintah di dalamnya, justru akan menimbulkan berbagai permasalahan yang menyulitkan pengembangan kawasan wisata. Untuk menjamin supaya pariwisata dapat berkembang secara baik dan berkelanjutan serta mendatangkan manfaat bagi daerah dan meminimalisasi dampak negatif yang timbul, pengembangan pariwisata perlu didahului dengan kajian yang mendalam, yakni dengan melakukan penelitian terhadap semua faktor daya pendukungnya.

Berdasarkan uraian diatas,kegiatan kepariwisataan merupakan salah satu bidang usaha yang dipandang dapat memberikan manfaat dan keuntungan bagi masyarakat, pengusaha, maupun pemerintah dalam meningkatkan pendapatan asli daerahnya. Hal tersebutlah yang membuat penulis tertarik untuk menganalisis bagaimana strategi pengembangan objek wisata Danau Linouw yang dilakukan pemerintah melalui Dinas Pariwisata Kota Tomohon ke dalam tesis yang berjudul: "Strategi Pengembangan Pariwisata Objek Wisata Danau Linouw Terhadap Peningkatan Pendapatan Asli Daerah (PAD) Kota Tomohon".

\section{Rumusan Masalah}

Berdasarkan latar belakang di atas, rumusan masalah dalam penelitian ini ialah bagaimana strategi pengembangan objek wisata Danau Linouw terhadap peningkatan pendapatan asli daerah (PAD) Kota Tomohon?

\section{Tujuan Penelitian}

Penelitian ini bertujuan untuk mengetahui strategi pengembangan kawasan wisata Danau Linouw untuk peningkatan Pendapatan Asli Daerah (PAD) Kota Tomohon.

\section{Manfaat Penelitian}

1. Manfaat Teoritis

a. Menambah khasanah ilmu pengetahuan khususnya dalam bidang pengembangan pembangunan. 
b. Dapat menambah literatur bahan kajian penelitian dalam pengembangan objek wisata Danau bagi peneliti-peneliti selanjutnya.

2. Manfaat Praktis

a) Bagi peneliti: menambah wawasan tentang strategi pengembangan objek wisata terhadap peningkatan pendapatan asli daerah secara keseluruhan dan secara khusus pada objek wisata Danau Linouw di Kota Tomohon.

b) Bagi pendidikan: menjadi salah satu sumbangan pemikiran dalam bidang pembangunan khususnya objek wisata.

c) Dinas Pariwisata : sebagai bahan masukan kepada Pemerintah Kota Tomohon khususnya Dinas Pariwisata dalam mengembangkan objek wisata khususnya kawasan Danau Linouw dan diharapkan dapat membantu Pemerintah Kota Tomohon dalam merumuskan strategi kebijakan yang tepat dalam pengembangan kawasan wisata Danau Linouw untuk peningkatan PAD Kota Tomohon.

\section{METODE PENELITIAN}

\section{Jenis Penelitian}

Penelitian dilakukan di Kota Tomohon. Penelitian dilaksanakan pada bulan Oktober Desember 2017.

\section{Jenis Penelitian}

Jenis penelitian menggunakan metode deskriptif dimana data dikumpulkan, dianalisis dan dideskripsikan dengan menggunakan pendekatan kuantitatif. Data kuantitatif berupa angka-angka seperti jumlah pengunjung yang datang ke Danau Linouw dan penentuan nilai bobot, rating, serta skor. Sumber data terdiri dari data primer dan data sekunder. Data primer diperoleh langsung dari lapangan melalui informan yang telah ditentukan, sedangkan data sekunder diperoleh dari instansi atau lembagalembaga yang terkait seperti Dinas Pariwisata, BPS, Perpustakaan dan dinas-dinas terkait lainnya.

\section{Penentuan Sampel}

Dalam penelitian ini, jumlah populasi yang dimaksud ialah seluruh pengunjung objek wisata dimana jumlahnya tidak diketahui secara pasti. Tidak diketahui secara pasti karena pengunjung yang datang setiap hari berbeda jumlahnya sehingga tidak bisa diprediksikan berapa orang yang akan berkunjung. Teknik pengambilan sampel yang diambil berdasarkan pertimbangan bahwa populasi yang ada tidak diketahui secara pasti jumlahnya sehingga menggunakan accidental samplingyaitu pengambilan sampel yang dilakukan kepada siapa saja yang kebetulan ada (Soeratno dan Lincolin, 2008). Selain itu responden yang merupakan informan yang ikut terlibat dalam penelitian ini, yaitu:

1. Dinas Pariwisata Kota Tomohon.

2. Dinas Pendapatan Daerah Kota Tomohon.

3. Camat

4. Lurah

5. Kepala Lingkungan

6. Pengelola objek wisata Danau Linouw.

7. Karyawan objek wisata Danau Linouw.

8. Tokoh masyarakat.

9. Masyarakat sekitar objek wisata Danau Linouw.

10. Wisatawan/pengunjung objek wisata Danau Linouw.

\section{Variabel Penelitian}

Variabel dalam penelitian ini terdiri dari:

1. Pengembangan Objek Wisata.

Pengembangan objek wisata secara operasional dalam penelitian ini didefinisikan sebagai upaya memajukan kawasan wisata Danau Linouw oleh Pemerintah Kota Tomohon dengan memanfaatkan berbagai sumber daya pariwisata baik secara internal maupun eksternal.

2. Peningkatan Pendapatan Asli Daerah (PAD).

Peningkatan Pendapatan Asli Daerah (PAD) dalam penelitian ini didefinisikan sebagai usaha untuk menambah penerimaan daerah yang diperoleh dari dikembangkannya kawasan wisata Danau Linouw.

\section{Teknik Pengumpulan Data}

Metode pengumpulan data yang digunakan adalah sebagai berikut: 
1. Wawancara, dalam penelitian ini dilakukan dengan bertanya langsung kepada wisatawan dan pengelola objek wisata Danau Linouw.

2. Observasi, dalam penelitian ini dengan cara pengamatan secara langsung di daerah yang bersangkutan yaitu objek wisata Danau Linouw, Kota Tomohon.Peneliti melakukan persiapan dan pengambilan data awal untuk mengetahui terlebih dahulu Faktor Strategi Eksternal (EFAS) yang meliputi peluang dan ancaman yang dapat diperoleh dari lingkungan luar kawasan Danau Linouw. Sementara itu, Faktor Strategi Internal (IFAS) meliputi kekuatan dan kelemahan yang diperoleh dari dalam kawasan Danau Linouw.

3. Kuesioner, melalui Data EFAS dan IFAS yang diperoleh sebelumnya, selanjutnya dibuatkan kuesioner atau matriks Faktor Strategi Eksternal (peluang dan ancaman) serta Faktor Strategi Internal (kekuatan dan kelemahan) dalam bentuk tabel dengan memberi bobot, rating dan skor pada masing-masing faktor strategi. Kuesioner yang dimaksud, yaitu melalui teknik pengumpulan data yang dilakukan dengan cara memberi seperangkat pertanyaan atau pernyataan tertulis kepada responden untuk dijawab menggunakan skala likert.

4. Dokumentasi, dalam penelitian ini dilakukan dengan menggunakan literaturliteratur dari perpustakaan, informasiinformasi daridokumen-dokumen tertulis, baik berupa arsip-arsip, buku-buku yang relevan tentang pendapat, teori, jurnaljurnal, surat kabar, majalah dan sumbersumber lainnya yang menunjang penelitian ini tertulis baik dari instansi terkait maupun berasal dari internet yang berhubungan dengan penelitian untuk memperoleh data sekunder.

\section{Jenis dan Sumber Data}

Jenis dan sumber datayang digunakan dalam penulisan ini adalah sebagai berikut :

1. Data primer yaitu data yang diperoleh secara langsung dari responden melalui daftar kuesioner yang diajukan kepada responden guna memperoleh data tanggapan responden mengenai faktor strategis eksternal dan faktor strategis internal.
2. Data sekunder yaitu data yang diperoleh dari Badan Pusat Statistik, Dinas Pariwisata, objek Wisata Danau Linouw, serta sumber pustaka yang ada.

\section{Teknik Analisis Data}

Pengelolaan data menggunakan analisis SWOTdan diproses melalui faktor-faktor internal dan eksternal. Analisis SWOT adalah identifikasi berbagai faktor secara sistematis untuk merumuskan strategi perusahaan. Analisis ini didasarkan pada logika yang dapat memaksimalkan kekuatan (Strengths) dan peluang (Opportunities), namun secara bersamaan dapat meminimalkan kelemahan (Weaknesses) dan ancaman (Threats).

Proses pengambilan keputusan strategis selalu berkaitan dengan pengembangan misi, tujuan, strategi, dan kebijakan perusahaan. Analisis SWOT membandingkan antara faktor eksternal peluang dan ancaman dengan faktor internal kekuatan dan kelemahan (Freddy Rangkuti, 2005).

\section{Faktor Eksternal}

Faktor eksternal adalah faktor-faktor berupa daya tarik wisata yang meliputi peluang dan ancaman dalam menarik wisatawan di obyek wisata Danau Linouw. Analisis eksternal yang meliputi peluang dan ancaman dilakukan untuk mengetahui posisi daerah dalam berhadapan dengan lingkungan eksternalnya. Menurut Pearce Robinson(2008), peluang merupakan situasi utama yang menguntungkan dalam lingkungan suatu perusahaan, sedangkan ancaman adalah situasi utama yang tidak menguntungkan dalam lingkungan suatu perusahaan.

\section{Faktor Internal}

Faktor internal adalah faktor-faktor berupa daya tarik wisata yang meliputi kekuatan dan kelemahan dalam menarik wisatawan di obyek wisata Danau Linouw. Analisis faktor internal yang meliputi kekuatan dan kelemahan dilakukan untuk mengetahui kondisi daerah tersebut secara internal. Menurut Pearce/ Robinson(2008), kekuatan merupakan sumber daya atau kapabilitas yang dikendalikan oleh atau tersedia bagi suatu perusahaan yang 
membuat perusahaan relative lebih unggul dibandingkan pesaingnya dalam memenuhi kebutuhan pelanggan yang dilayaninya sedangkan kelemahan adalah keterbatasan atau kekurangan dalam satu atau lebih sumber daya atau kapabilitas suatu perusahaan relatif terhadap pesaingnya, yang menjadi hambatan dalam memenuhi kebutuhan peanggan secara efektif.

Metode SWOT digunakan untuk mengetahui metode strategi pengembangan melalui analisis SWOT dengan cara menganalisis faktor-faktor eksternal (peluang dan ancaman) dan faktor-faktor internal(kekuatan dan kelemahan) dengan matriks EFE dan IFE. Matriks External Factor Evaluation (EFE) digunakan untuk menganalisis faktor-faktor yang berupa peluang dan ancaman yang dihadapi. Data faktor eksternal dicari untuk menganalisis hal-hal yang berkaitan dengan persoalan ekonomi, budaya, sosial, lingkungan, demografi, politik, hukum, pemerintahan, teknologi, dan persaingan pasar. Matriks Internal Factor Evaluation (IFE) digunakan untuk menganalisis faktor-faktor yang berupa kekuatan dan kelemahan yang dimiliki. Data faktor internal dicari untuk menganalisis hal-hal yang berkaitan dengan beberapa fungsional perusahaan, misalnya dari aspek manajemen, keuangan, sumber daya manusia, pemasaran, sistem informasi, dan produksi.

Selanjutnya dilakukan penyusunan strategi dengan menggunakan analisis SWOT. Semua elemen dalam SWOT akan dijaring melalui jawaban responden terhadap pertanyaan yang diajukan. Berikut adalah tahap-tahap dalam penyusunan analisis SWOT:

1. Matrik Faktor Strategi Eksternal.

Sebelum membuat matrik faktor strategi eksternal, perlu mengetahui terlebih dahulu faktor strategi eksternal (EFE). Berikut ini adalah cara-cara penentuanFaktor Strategi Eksternal (EFE) :

a. Susunlah dalam kolom 1daftar faktorfaktor utama yang mempunyai dampak penting pada kesuksesan atau kegagalan usaha yang terdiri berbagai peluang (opportunities) dan ancaman (threats). b. Beri bobot masing-masing faktor dalam kolom 2. Jumlah seluruh bobot harus sebesar 1,0. Nilai bobot dicari dan dihitung berdasarkan rata-rata industrinya. Nilai bobot yang ditentukan adalah :

- 0,20 atau $20 \%$ : Kuat atau tinggi

- 0,15 atau $15 \%$ : Diatas rata-rata

- 0,10 atau $10 \%$ : Rata-rata

- 0,05 atau 5\%: Dibawah rata-rata

- 0,00 atau 0\%: Tidak terpengaruh

c. Hitung rating (dalam kolom 3) untuk masing-masing faktor dengan memberikan skala mulai dari 4 (sangat kuat) sampai dengan 1 (sangat lemah) berdasarkan pengaruh faktor tersebut terhadap kondisi perusahaan yang bersangkutan. Pemberian nilai rating untuk faktor peluang bersifat positif (peluang yang semakin besar diberi rating +4 , tetapi jika peluangnya kecil, diberi rating +1$)$. Pemberian nilai rating ancaman adalah kebalikannya. Misalnya jika nilai ancamannya sangat besar, ratingnya adalah 1. Sebaliknya, jika nilai ancamannya sedikit ratingnya 4 . Rating ditentukan berdasarkan efektivitas strategi objek wisata Danau Linouw. Dengan demikian, nilainya didasarkan pada kondisi objek wisata tersebut.

d. Kalikan bobot pada kolom 2 dengan rating pada kolom 3, untuk memperoleh faktor pembobotan dalam kolom 4 . Hasilnya berupa skor pembobotan untuk masing-masing faktor.

e. Gunakan kolom 5 untuk memberikan komentar atau catatan mengapa faktorfaktor tertentu dipilih dan bagaimana skor pembobotannya dihitung.

f. Jumlahkan skor pembobotan (pada kolom 4), untuk memperoleh total skor pembobotan bagi perusahaan yang bersangkutan. Nilai total ini menunjukkan bagaimana perusahaan tertentu bereaksi terhadap faktor-faktor strategis eksternalnya. Total skor ini dapat digunakan untuk membandingkan perusahaan lainnya dalam kelompok industri yang sama. 
2. Matrik Faktor Strategi Internal.

Setelah faktor-faktor strategis internal suatu perusahaan diidentifikasi, suatu tabel IFAS disusun untuk merumuskan faktorfaktor strategis internal tersebut dalam kerangka kekuatan dan kelemahan perusahaan. Tahapnya adalah :

a. Susunlah dalam kolom 1 yang terdiri dari faktor-faktor yang menjadi kekuatan serta kelemahan perusahaan.

b. Beri bobot masing-masing faktor dalam kolom 2. Faktor-faktor tersebut kemungkinan dapat memberikan dampak terhadap faktor strategis. (Semua bobot tersebut jumlahnya tidak boleh melebihi skor total 1,00).

c. Hitung rating (dalam kolom 3) untuk masing-masing faktor dengan memberikan skala mulai dari 4 (sangat kuat) sampai dengan 1 (sangat lemah) berdasarkan pengaruh faktor tersebut terhadap kondisi perusahaan yang bersangkutan. Variabel yang bersifat positif (semua variabel yang masuk kategori kekuatan) diberi nilai mulai dari +1 sampai dengan +4 (sangat baik) dengan membandingkannya dengan rata-rata industri atau dengan pesaing utama. Sedangkan variabel yang bersifat negatif, kebalikannya. Contohnya, jika kelemahan perusahaan besar sekali dibandingkan dengan rata-rata industri, nilainya adalah 1, sedangkan jika kelemahan perusahaan di bawah ratarata industri, nilainya adalah 4 . Rating mengacu pada kondisi objek wisata Danau Linouw, sedangkan bobot mengacu pada industri pariwisata di mana objek wisata Danau Linouw berada.

d. Kalikan bobot pada kolom 2 dengan rating pada kolom 3, untuk memperoleh faktor pembobotan dalam kolom 4 . Hasilnya berupa skor pembobotan untuk masing-masing faktor yang nilainya bervariasi mulai dari 4 sampai dengan 1 .

e. Gunakan kolom 5 untuk memberikan komentar atau catatan mengapa faktorfaktor tertentu dipilih dan bagaimana skor pembobotannya dihitung. f. Jumlahkan skor pembobotan (pada kolom 4), untuk memperoleh total skor pembobotan bagi perusahaan yang bersangkutan. Nilai total ini menunjukkan bagaimana perusahaan tertentu bereaksi terhadap faktor-faktor strategis internalnya. Total skor ini dapat digunakan untuk membandingkan perusahaan lainnya dalam kelompok industri yang sama.

3. Analisis Internal Eksternal.

Matrix IE terdiri dari dua dimensi yaitu skor total dari FE matrix pada sumbu $\mathrm{X}$ dan skor total dari EFE matrix pada sumbu Y. Ingat kembali bahwa suatu organisasi harus membuat matriks FE dan matriks EFE dalam kaitannya dengan organisasi. Skor bobot total yang diperoleh memungkinkan susunan matriks IE dalam suatu perusahaan. Pada sumbu $\mathrm{x}$ dari matriks IE, skor bobot IFE total 1,0 sampai 1,99 menunjukkan posisi internal yang lemah; skor 2,0 sampai 2,99 dianggap sedang; dan skor 3,0 sampai 4,0 adalah kuat. Serupa dengannya, pada sumbu y, skor bobot EFE total 1,0 sampai 1,99 dipandang rendah; skor 2,0 sampai 2,99 dianggap sedang; dan skor 3,0 hingga 4,0 adalah tinggi (Umar, 1999).

4. Analisis SWOT.

Menurut Freddy Rangkuti, Matriks IE didasari pada dua dimensi kunci yaitu total rata-rata tertimbang IFE pada sumbu xdan total rata-rata tertimbang EFE pada sumbu yuntuk mendapatkan strategi yang tepat berdasarkan hasil matriks IFE dan matriks EFE.

Matriks IE dapat dibagi menjadi tiga daerah utama yang memiliki implikasi strategi berbeda, yaitu sebagai berikut :

1. Rekomendasi untuk divisi yang masuk dalam sel I, II, IV dapat digambarkan sebagai "tumbuh dan kembangkan". Strategi intensif (penetrasi pasar, pengembangan pasar, dan pengembangan produk) atau strategi integratif (intregasi ke belakang, integrasi ke depan, dan integrasi horizontal) paling sesuai untuk divisi-divisi ini. 
2. Divisi yang masuk dalam sel III, V, VII dapat dikelola dengan cara terbaik dengan strategi "jaga dan pertahankan" ; penetrasi pasar dan pengembangan produk adalah dua strategi yang umum digunakan untuk divisi tipe ini.

3. Rekomendasi yang umum diberikan untuk divisi yang masuk dalam sel VI, VIII, dan IX adalah "tuai atau divestasi", organisasi yang berhasil mampu mencapai portofolio bisnis yang diposisikan dalam atau sekitar sel I dalam matriks IE

\section{HASIL DAN PEMBAHASAN}

\section{Hasil Penelitian}

\section{Deskripsi Umum Lokasi Penelitian}

\section{Keadaan Geografis}

Secara astronomis Kota Tomohon terletak di antara $1^{0} 15^{`}$ Lintang Utara dan $124^{0} 50^{`}$ Bujur Timur. Hal ini menunjukkan bahwa lokasi penelitian berada pada daerah yang beriklim tropis dengan memiliki dua tipe musim yaitu musim kemarau dan musim penghujan dan terletak pada ketinggian rata-rata 700-800 meter dari permukaan laut yang menyebabkan suhu udara sangat sejuk antara $19-29^{\circ} \mathrm{C}$.

Kondisi topografi berbeda-beda dengan kemiringan lereng mulai dari datar dan bergelombang antara $0-5 \%$ sampai bukit dan bergunung antara $10-25 \%$ lebih serta diapit oleh 2 (dua) gunung berapi aktif, yaitu Gunung Lokon $(1.689 \mathrm{~m})$ dan Gunung Mahawu $(1.311 \mathrm{~m})$.

Kota Tomohon memiliki batas-batas wilayah secara administratif dengan Kabupaten lain, yaitu:

a. Sebelah Utara berbatasan dengan Kecamatan Pineleng Kabupaten Minahasa

b. Sebelah Selatan berbatasan dengan Kecamatan Sonder Kabupaten Minahasa

c. Sebelah Barat berbatasan dengan Kecamatan Tombariri Kabupaten Minahasa

d. Sebelah Timur berbatasan dengan Kecamatan Tondano Utara Kabupaten Minahasa.

Luas wilayah Kota Tomohon secara keseluruhan sekitar 147,21 $\mathrm{km}^{2}$ dengan masingmasing luas wilayah per kecamatan dapat dilihat pada Tabel 1 di bawah ini:
Tabel 1. Luas Wilayah Menurut Kecamatan 2018

\begin{tabular}{clcr}
\hline No & Kecamatan & Luas $\left(\mathbf{K m}^{\mathbf{2}}\right)$ & Persentase \\
\hline 1 & Tomohon Selatan & 32,95 & 22,38 \\
2 & Tomohon Tengah & 9,41 & 6,39 \\
3 & Tomohon Timur & 21,88 & 14,86 \\
4 & Tomohon Barat & 40,69 & 27,64 \\
5 & Tomohon Utara & 42,28 & 28,72 \\
\hline Kota & Tomohon & 147,21 & 100 \\
\hline
\end{tabular}

Sumber : Hasil Analisis Data 2018

\section{Kondisi Demografi}

Mayoritas penduduk Kota Tomohon adalah suku Minahasa dengan sub-suku Tombulu namun sebagian juga terdapat sub-suku Toutemboan yang mendiami ujung Utara Kota Tomohon yaitu tepatnya di Kelurahan Tinoor yang terdiri dari Tinoor Satu dan Tinoor Dua. Penduduk lain juga mendiami di Kota Tomohon baik berasal dari suku Minahasa maupun suku lain di Indonesia. Dalam kehidupan sehari-hari penduduk di Kota Tomohon menggunakan Bahasa Manado sebagai bahasa percakapan dan bahasa daerah menggunakan bahasa Tombulu namun secara nasional menggunakan bahasa Indonesia.

Jumlah penduduk Kota Tomohon secara keseluruhan adalah 95.157 jiwa dengan ketentuan bahwa laki-laki sebanyak 47.898 jiwa dan perempuan sebanyak 46.259 jiwa. Selengkapnya penyebaran jumlah penduduk Kota Tomohon per kecamatan diuraikan pada Tabel 2 berikut:

Tabel 2. Luas Wilayah Menurut Kecamatan 2018

\begin{tabular}{|c|c|c|c|c|c|}
\hline \multirow[t]{2}{*}{ No } & \multirow[t]{2}{*}{ Kecamatan } & \multicolumn{4}{|c|}{ Penduduk } \\
\hline & & Laki-Laki & Perempu & Jumlah & $\%$ \\
\hline 1 & Tomohon Selatan & 11089 & 10593 & 21682 & 22.78 \\
\hline 2 & Tomohon Tengah & 10280 & 11049 & 21329 & 22.41 \\
\hline 3 & Tomohon Timur & 5331 & 5122 & 10453 & 10.98 \\
\hline 4 & Tomohon Barat & 7275 & 6988 & 14263 & 14.98 \\
\hline 5 & Tomohon Utara & 13922 & 13507 & 27430 & 28.82 \\
\hline & Kota Tomohon & 47898 & 46259 & 95157 & 100 \\
\hline
\end{tabular}

Data Tabel 2 di atas menunjukkan bahwa penyebaran jumlah penduduk Kota Tomohon yang paling banyak berada pada Kecamatan Tomohon Utara dengan jumlah 27.430 jiwa atau $28.82 \%$ dan diikuti Kecamatan Tomohon Selatan dengan jumlah 21.682 jiwa atau $22.78 \%$, serta Kecamatan Tomohon Tengah sebanyak 21.329 jiwa atau $22.41 \%$, Kecamatan Tomohon Barat sebanyak 14.263 atau $14.98 \%$, dan jumlah penduduk yang paling sedikit berada pada Kecamatan Tomohon Timur sebanyak 10.453 atau $10.98 \%$ dari jumlah penduduk secara keseluruhan. 


\section{Karakteristik Kota Tomohon}

\section{Pendidikan}

Sejak dulu Kota Tomohon dikenal sebagai Kota pendidikan dan Kota Agama karena di sinilah para misionaris dari negeri Belanda menetap dan membuka sekolah-sekolah, rumah sakit dan menjadi pusat penyebaran agama Kristen di Tanah Minahasa. Kota Tomohon memiliki fasilitas pendidikan mulai dari Taman Kanak-kanak (TK) hingga perguruan tinggi dan universitas.

Selanjutnya diuraikan melalui Tabel 3 tentang keadaan pendidikan menurut jumlah sekolah, guru dan murid pada tingkat SD, SLTP dan SMA yang ada di Kota Tomohon berdasarkan Data Badan Pusat Statistik 2013 Kota Tomohon.

Tabel 3. Jumlah Sekolah, Guru dan Murid SD Menurut

\begin{tabular}{clccc}
\multicolumn{7}{c}{ Kecamatan } & & & \\
\hline No & Kecamatan & $\begin{array}{c}\text { Jumlah } \\
\text { Sekolah }\end{array}$ & $\begin{array}{c}\text { Jumlah } \\
\text { Guru }\end{array}$ & $\begin{array}{c}\text { Jumlah } \\
\text { Murid }\end{array}$ \\
\hline 1 & Tomohon Selatan & 17 & 182 & 1973 \\
2 & Tomohon Tengah & 10 & 131 & 2042 \\
3 & Tomohon Timur & 7 & 88 & 1275 \\
4 & Tomohon Barat & 13 & 144 & 1734 \\
5 & Tomohon Utara & 17 & 182 & 2721 \\
\hline & Kota Tomohon & 64 & 727 & 9745 \\
\hline
\end{tabular}

Sumber: BPS Kota Tomohon 2018

Jumlah sekolah, guru dan murid SD di Kota Tomohon bervariasi antara satu Kecamatan dengan Kecamatan lain yaitu Kecamatan Tomohon Selatan jumlah SD sebanyak 17 sekolah, guru 182 orang dan murid sebanyak 1973 orang. Kecamatan Tomohon Tengah jumlah SD sebanyak 10 sekolah dan guru 131 orang dengan jumlah murid sebanyak 2042 orang. Kecamatan Tomohon Timur SD sebanyak 7 sekolah dan guru 88 orang dengan jumlah murid sebanyak 1275 orang. Kecamatan Tomohon Barat jumlah SD sebanyak 13 sekolah dan guru 144 orang dengan jumlah siswa sebanyak 1734 orang serta Kecamatan Tomohon Utara SD sebanyak 17 sekolah dan guru 182 orang dengan jumlah murid sebanyak 2721 orang.

\section{Agama dan Kepercayaan}

Mayoritas masyarakat Kota Tomohon memeluk agama Kristen dan menjadi pusat penyebaran agama Kristen Protestan di Minahasa. Kantor pusat Sinode Gereja Masehi Injili di Minahasa (GMIM) yang adalah gereja terbesar yang ada di Sulawesi Utara, berlokasi di Kota Tomohon. Demikian juga dengan Gereja Katolik Roma yang memiliki banyak pemeluk dengan sejarah yang panjang di Kota Tomohon. Kantor Konferensi Gereja Masehi Advent Hari Ketujuh wilayah Tomohon dan Minahasa Selatan juga terletak di Kota Tomohon.

Di Tomohon juga terdapat pemeluk agama lain selain agama Kristen yaitu agama Budha dan Islam. Tempat ibadah umat Budha yaitu vihara berada di Kelurahan Kakaskasen III, sedangkan masyarakat yang beragama Islam menetap di Kelurahan Kampung Jawa dan terdapat juga pesantren di Kelurahan Kinilow.

\section{Ekonomi dan Perdagangan}

Kota Tomohon dikenal sebagai Kota Bunga (kembang) karena Tomohon adalah daerah penghasil bunga terbesar di Provinsi Sulawesi Utara dan selain itu Kota Tomohon juga dikenal sebagai salah satu produsen sayur mayur dan tanaman holtikultura lainnya.

Tidak hanya itu, letaknya yang diapit oleh tiga gunung berapi aktif yaitu Gunung Lokon, Mahawu dan Masarang menjadikan wilayah ini sebagai daerah yang subur dan sebagai daerah wisata karena hawanya yang sejuk. Pasar Tomohon dulunya adalah pasar tradisional terbesari di Minahasa karena menjual berbagai macam jenis daging. Daging yang dijual sangat segar karena baru di sembelih di rumah potong hewan di pasar tersebut. Selain itu, Pasar Tomohon juga menjual berbagai jenis ikan laut dan ikan air tawar karena Pasar Tomohon lebih lengkap sehingga banyak pedagang yang datang berbelanja di Pasar Tomohon dalam jumlah besar.

\section{Karakteristik Responden}

Responden penelitian berjumlah 20 orang dan memiliki karakteristik yang berbeda sehingga perlu dijelaskan melalui beberapa kategori yaitu pendidikan, jenis kelamin, umur, agama dan status perkawinan serta pekerjaan responden.

\section{Jenis Kelamin Responden}

Jenis kelamin responden berdasarkan berdasarkan Tabel 4 menunjukkan bahwa responden laki-laki sebanyak 9 orang atau $60 \%$ dan responden perempuan sebanyak 6 orang atau $40 \%$ dari keseluruhannya. 
Tabel 4. Jenis Kelamin Responden

\begin{tabular}{clcr}
\hline No & Jenis Kelamin & Frekuensi & Persentase \\
\hline 1 & Laki-Laki & 12 & 60 \\
2 & Perempuan & 8 & 40 \\
\hline Jumlah & & 20 & 100 \\
\hline \multicolumn{2}{l}{ Sumber: } & Hasil Analisis Data 2018 &
\end{tabular}

\section{Usia Responden}

Data Tabel 5 menunjukkan bahwa usia responden antara 21 sampai 30 tahun sebanyak 5 orang atau $33.33 \%$ dan usia 31 sampai 40 tahun sebanyak 6 orang atau $26.67 \%$ serta responden yang berumur 41 sampai 50 sebanyak 4 orang atau $26.67 \%$, sedangkan usia antara 0 sampai 21 , dan 51 sampai di atas 60 tahun tidak ada.

\begin{tabular}{|c|c|c|c|}
\hline No & Usia & Frekuensi & Persentase \\
\hline 1 & $21-30$ & 7 & 33.33 \\
\hline 2 & $31-40$ & 8 & 40 \\
\hline 3 & $41-50$ & 5 & 26.67 \\
\hline & Jumlah & 20 & 100 \\
\hline
\end{tabular}

\section{Agama Responden}

Berdasarkan Tabel 6 menunjukkan bahwa responden yang menganut agama Kristen sebanyak 9 orang atau 60\%, Kristen Katolik sebanyak 4 orang atau $26.67 \%$ dan Islam sebanyak 2 orang atau $13.33 \%$ serta responden yang beragama Hindu, Budha dan lain-lain tidak ada.

Tabel 6. Agama Responden

\begin{tabular}{llcr}
\hline No & Agama & Frekuensi & Persentase \\
\hline 1 & Kristen Protestan & 11 & 60 \\
2 & Kristen Katolik & 5 & 26.67 \\
3 & Islam & 4 & 13.33 \\
4 & Hindu & - & - \\
5 & Budha & - & - \\
6 & Lain-lain & - & - \\
\hline Jumlah & 20 & 100 \\
\hline
\end{tabular}

Sumber: Hasil Analisis Data 2018

\section{Pendidikan Responden}

Data Tabel 7 menunjukkan bahwa jumlah respondenyang berpendidikan Sekolah Menengah Atas/SMA sebanyak 6 orang atau $40 \%$, Strata Satu /S1 sebanyak 5 orang atau $33.33 \%$, dan Strata Dua / S2 sebanyak 4 orang 26.67\% serta Sekolah Dasar / SD, Sekolah Lanjutan Tingkat Pertama / SLTP, Diploma dan Strata Tiga / S3 belum ada dari keseluruhan responden.
Tabel 7. Pendidikan Responden

\begin{tabular}{clcr}
\hline No & Pendidikan & Frekuensi & Persentase \\
\hline 1 & SMA & 9 & 40 \\
2 & Diploma & - & - \\
3 & S1 & 7 & 33.33 \\
4 & S2 & 4 & 26.67 \\
5 & S3 & - & - \\
\hline & Jumlah & 20 & 100 \\
\hline
\end{tabular}

Sumber: Hasil Analisis Data 2018

\section{Pekerjaan Responden}

Berdasarkan Tabel 8 menunjukkan bahwa responden yang bekerja sebagai Pegawai Negeri Sipil (PNS) sebanyak 8 orang atau $53.33 \%$ tenaga honorer tidak ada dan swasta sebanyak 7 orang atau $47.67 \%$ serta pengusaha, petani, nelayan dan peternak tidak dari keseluruhan responden.

\begin{tabular}{llcr}
\multicolumn{4}{l}{ Tabel 8. PekerjaanResponden } \\
\hline No & Pekerjaan & Frekuensi & Persentase \\
\hline 1 & PNS & 10 & 53.33 \\
2 & Honorer & 1 & - \\
3 & Swasta & 7 & 46.67 \\
4 & Pengusaha & 2 & - \\
\hline \multicolumn{2}{l}{ Jumlah } & 20 & 100 \\
\hline \multicolumn{4}{l}{ Sumber: Hasil Analisis Data 2018 }
\end{tabular}

\section{Hasil Analisis SWOT}

Analisis SWOT didasarkan pada logika untuk memaksimalkan kekuatan (Strength) dan peluang (Opportunitiess), namun secara bersamaan dapat meminimalkan kelemahan (Weakness) dan ancaman (Treath).Analisis faktor internal dan eksternal dipakai untuk mengetahui kekuatan dan kelemahan, serta mampu mengurangi kelemahan yang ada dan pada saat yang sama memaksimalkan kekuatan. Hal yang sama juga berlaku pada ancaman dan peluang, di mana pada saat ancaman dapat diperkecil, peluang yang ada justru diperbesar.

Hasil analisis terhadap kondisi yang dihadapi dalam mengembangkan objek wisata di Danau Linouw Kota Tomohon yang meliputi analisis kondisi internal dan analisis kondisi eksternal sebagai berikut

\section{Analisis Faktor Internal (IFAS)}

Analisis lingkungan internal yang dilakukan yaitu terhadap faktor-faktor strategis internal yang terdiri dari kekuatan dan kelemahan dalam pengembangan objek wisata danau Linouw Kota Tomohon. Adapun faktor-faktor strategis internal tersebut antara lain:

a. Kekuatan (S), meliputi:

1) Keindahan objek wisata

2) Kesejukan di area objek wisata 
3) Keramahan pelayan dan masyarakat sekitar

4) Kebersihan diobjek wisata

5) Keamanan dilokasi objek wisata

6) Lokasi yang mudah diakses

b. Kelemahan (W), meliputi:

1) Tidak adanya atraksi wisata

2) Minimnya pemasaran objek wisata

3) Kurangnya ketersediaan penjualan marchendise

4) Prasarana jalan yang sempit

5) Kurang nampaknya petugas keamanan

6) Kuliner kurang variatif

Setelah melakukan analisis kondisi lingkungan internal, selanjutnya dilakukan penghitungan bobot dan rating internal untuk mengetahui letak strategis objek wisata danau Linouw yang dianggap perlu untuk dilakukan pengembangan. Penghitungan bobot faktor tersebut dilakukan dengan membuat tabulasi data skor IFAS (Internal Strategic Factor Analysis Summary) dilihat pada lampiran. Penghitungan bobot dengan ketentuan bobot 0.00 tidak penting sampai 1.00 sangat penting, kemudian setiap faktor diranking atau dinilai berdasarkan faktor yang bersangkutan berupa angka 4 (sangat superior), 3 (di atas rata-rata), 2 (rata-rata), dan 1 ( di bawah rata-rata atau jelek). Dengan mengalikan bobot dan rating maka diperoleh nilai masingmasing raktor yang kemudian dijumlahkan untuk memperoleh hasil nilai total IFAS yang diuraikan pada Tabel 9 berikut.

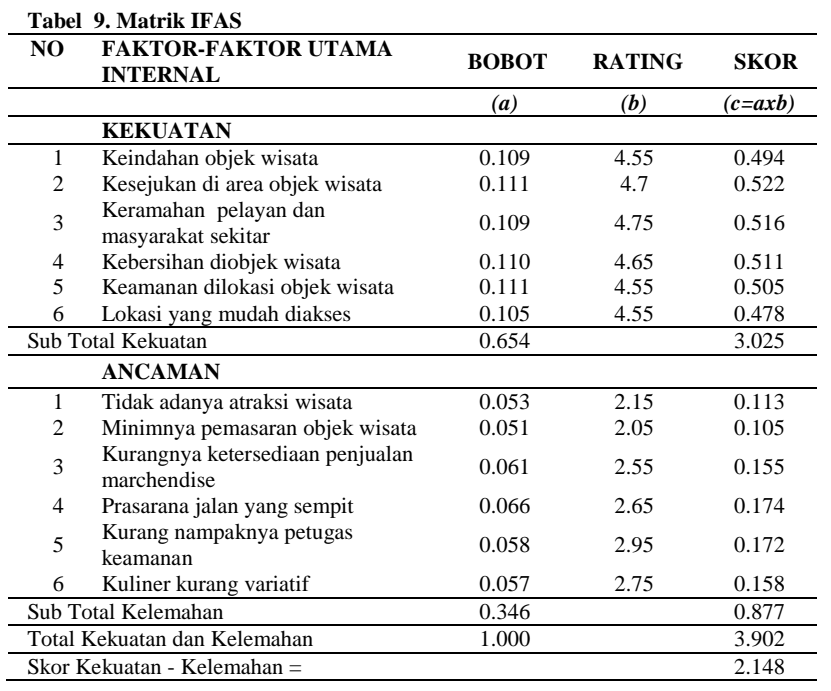

Berdasarkan hasil analisis faktor strategis internal pada Tabel 9 di atas menunjukkan bahwa skor total hasil analisis internal adalah 3.902 yang menandakan objek wisata Danau Linouw Tomohon berada pada posisi "kuat" dalam memanfaatkan kekuatan untuk menghadapi kelemahan yang dihadapi dalam pengembangan objek wisata Danau Linouw Tomohon. Hal ini berarti bahwa pengembangan objek wisata Danau Linouw Tomohon telah mampu mengatasi kelemahannya dengan memanfaatkan kekuatan yang dimiliki karena berada pada posisi di atas rata- rata (2.00). Kekuatan utama dari pengembangan obyek wisata Danau Linouw terdapat pada faktor kesejukan dengan skor internal 0.522, selanjutnya diikuti secara berurutan oleh faktor keindahan, kebersihan, keamanan danlokasi yang mudah diakses. Dengan demikian semakin banyak pilihan yang ditawarkan, semakin mempermudah wisatawan untuk menentukan pilihannya.

Adapun kelemahan utama yang ada pada objek wisata Danau Linouw Tomohon terletak pada minimnya pemasaran objek wisata (0.049), selanjutnya diikuti secara berurutan faktor kurang nampaknya petugas keamanan, prasarana jalan yang sempit, kurangnya ketersediaan penjualan marchendise, tidak adanya atraksi wisata dan kuliner yang kurang variatif dengan skor internal. Sebagai objek wisata yang banyak dikenal oleh masyarakat, harga wisata yang ditawarkan saat ini relatif lebih mahal dibandingkan dengan objek wisata lainnya yang ada di Kota Tomohon Sulawesi Utara.

\section{Analisis Faktor Eksternal (EFAS)}

Alasan kondisi eksternal dilakukan terhadap faktor-faktor strategis yang terdiri atas peluang dan ancaman dalam pengembangan objek wisata Danau Linouw Kota Tomohon. Adapun faktor-faktor strategis eksternal yang dimaksud antara lain:

a. Peluang $(\mathrm{O})$, meliputi:

1) Kebijakan pemerintah daerah dan pusat yang mendukung dalam mengembangkan pariwisata

2) Diseminasi informasi dengan kemajuan teknologi

3) Membentuk citra positif bagi wisatawan lain

4) Memberikan pendapatan bagi daerah

5) Minat masyarakat terhadap pariwisata

6) Terbukanya lapangan kerja bagi masyarakat sekitar 
b. Ancaman (T), meliputi:

1) Adanya gunung merapi aktif di sekitar obyek wisata

2) Efek bau belerang dari objek wisata

3) Ketertiban Lalu lintas menuju objek wisata

4) Berdekatannya objek wisata dengan daerah lain

Setelah menganalisis kondisi lingkungan eksternal, selanjutnya dilakukan penghitungan bobot dan rating faktor eksternal untuk mengetahui letak strategis objek wisata Danau Linouw yang dianggap perlu untuk dilakukan pengembangan. Penghitungan bobot faktor tersebut dilakukan dengan membuat tabulasi data skor EFAS (External Strategic Factor Analysis Summary) dilihat pada lampiran. Penghitungan bobot dengan ketentuan bobot 0.00 tidak penting sampai 1.00 sangat penting, kemudian setiap faktor diranking atau dinilai berdasarkan faktor yang bersangkutan berupa angka 4 (sangat superior), 3(di atas rata-rata), 2 (rata-rata), dan 1 (di bawah rata-rata). Dengan mengalikan bobot dan rating maka diperoleh nilai masing-masing faktor yang kemudian dijumlahkan untuk memperoleh hasil nilai total EFAS yang diuraikan pada Tabel 10 berikut:

Tabel 10. Matrik EFAS

\begin{tabular}{|c|c|c|c|c|}
\hline \multirow[t]{2}{*}{ NO } & $\begin{array}{l}\text { FAKTOR-FAKTOR } \\
\text { UTAMA EKSTERNAL }\end{array}$ & ВОВОТ & RATING & SKOR \\
\hline & & (a) & (b) & $(c=a x b)$ \\
\hline \multicolumn{5}{|c|}{ PELUANG } \\
\hline 1 & $\begin{array}{l}\text { Kebijakan pemerintah } \\
\text { daerah dan pusat yang } \\
\text { mendukung dalam } \\
\text { mengembangkan pariwisata }\end{array}$ & 0.110 & 4.15 & 0.457 \\
\hline 2 & $\begin{array}{l}\text { Kesejukan di area objek } \\
\text { wisata }\end{array}$ & 0.111 & 4.7 & 0.522 \\
\hline 3 & $\begin{array}{l}\text { Keramahan pelayan dan } \\
\text { masyarakat sekitar }\end{array}$ & 0.109 & 4.75 & 0.516 \\
\hline 4 & Kebersihan diobjek wisata & 0.110 & 4.65 & 0.511 \\
\hline 5 & $\begin{array}{l}\text { Keamanan dilokasi objek } \\
\text { wisata }\end{array}$ & 0.111 & 4.55 & 0.505 \\
\hline 6 & Lokasi yang mudah diakses & 0.105 & 4.55 & 0.478 \\
\hline \multicolumn{2}{|c|}{ Sub Total Kekuatan } & 0.654 & & 3.025 \\
\hline \multicolumn{5}{|c|}{ KELEMAHAN } \\
\hline 1 & Tidak adanya atraksi wisata & 0.053 & 2.15 & 0.113 \\
\hline 2 & $\begin{array}{l}\text { Minimnya pemasaran objek } \\
\text { wisata }\end{array}$ & 0.051 & 2.05 & 0.105 \\
\hline 3 & $\begin{array}{l}\text { Kurangnya ketersediaan } \\
\text { penjualan marchendise }\end{array}$ & 0.061 & 2.55 & 0.155 \\
\hline 4 & Prasarana jalan yang sempit & 0.066 & 2.65 & 0.174 \\
\hline 5 & $\begin{array}{l}\text { Kurang nampaknya petugas } \\
\text { keamanan }\end{array}$ & 0.058 & 2.95 & 0.172 \\
\hline 6 & Kuliner kurang variatif & 0.057 & 2.75 & 0.158 \\
\hline \multicolumn{2}{|c|}{ Sub Total Kelemahan } & 0.346 & & 0.877 \\
\hline \multirow{2}{*}{\multicolumn{2}{|c|}{$\begin{array}{l}\text { Total Kekuatan dan Kelemahan } \\
\text { Skor Kekuatan - Kelemahan }=\end{array}$}} & 1.000 & & 3.902 \\
\hline & & & & 2.148 \\
\hline
\end{tabular}

Hasil analisis faktor strategis eksternal melalui peluang dan ancaman mendapat skor total analisis eksternalnya adalah 3.495 yang menandakan bahwa pengembangan objek wisata Danau Linouw Tomohon berada pada posisi eksternal "kuat" dalam memanfaatkan peluang untuk mengatasi ancaman yang dihadapi. Hal ini berarti bahwa pengembangan objek wisata Danau Linouw Tomohon merespon dengan baik terhadap peluang dan mampu mengatasi ancaman, sehingga dapat meminimalkan dampak dari ancaman yang mungkin timbul. Peluang utama dalam pengembangan objek wisata Danau Linouw Tomohon terdapat pada faktor minat masyarakat terhadap pariwisata dengan skor eksternal 0.642, selanjutnya diikuti secara berurutan oleh faktor memberikan pendapatan bagi daerah, membentuk citra positif bagi wisatawan lain, kebijakan pemerintah daerah dan pusat yang mendukung dalam mengembangkan pariwisata, diseminasi informasi dengan kemajuan teknologi, dan terbukanya lapangan kerja bagi masyarakat sekitar. Dengan adanya perkembangan teknologi yang semakin maju dapat memberi peluang untuk meningkatkan wisatawan berkunjung di objek wisata Danau Linouw Tomohon.

Adapun ancaman utama yang ada pada pengembangan objek wisata Danau Linouw Tomohon adalah adanya gunung merapi aktif di sekitar obyek wisata dengan skor eksternal 0.211, selanjutnya diikuti secara berurutan oleh faktor ketertiban lalu lintas menuju objek wisata, efek bau belerang dari objek wisata, berdekatannya objek wisata dengan daerah lain. Hal tersebut memungkinkan terjadi karena adanya persaingan pariwisata antar objek wisata yang ada di Kota Tomohon maupun Sulawesi Utara pada umumnya sehingga mengakibatkan menurunnya jumlah kunjungan wisatawan yang berkunjung di objek wisata Danau Linouw Tomohon.

\section{Analisis Internal-Eksternal (IE)}

Berdasarkan hasil analisis strategi faktor internal dan faktor eksternal dapat dimasukkan hasilnya ke dalam matrik internal-eksternal sebagai tahap pencocokan strategi pengembangan objek wisata Danau Linouw Tomohon. Dari hasil analisis sebelumnya telah didapatkan nilai skor total IFAS adalah 3.902 dan EFAS adalah 3.495. Hasil skor total matrik IFAS tersebut berada pada sumbu $X$ dan skor total dari matrik EFAS berada pada sumbu Y. Posisi pengembangan objek wisata Danau Linouw dapat dilihat pada Tabel 11 Matrik IE berikut: 
Tabel 11. Matriks IE Objek Wisata Danau Linouw Tomohon Skor Bobot Total IFAS

\begin{tabular}{|c|c|c|c|c|c|c|c|}
\hline & & $\begin{array}{l}\text { Kuat } \\
3.00-4.00\end{array}$ & & $\begin{array}{l}\text { Sedang } \\
2.00-2.99\end{array}$ & & $\begin{array}{l}\text { Lemah } \\
1.00-199\end{array}$ & \\
\hline & 4 & & 3 & & 2 & & 1 \\
\hline $\begin{array}{l}\text { Tinggi } \\
3.00-4.00\end{array}$ & 3 & I & & II & & III & \\
\hline $\begin{array}{l}\text { Sedang } \\
2.00-2.99\end{array}$ & 2 & IV & & V & & VI & \\
\hline $\begin{array}{l}\text { Lemah } \\
1.00-199\end{array}$ & 1 & VII & & VIII & & IX & \\
\hline
\end{tabular}

Sumber: Hasil Analisis Data IE, 2018.

Berdasarkan skor pembobotan total pada matriks internal-eksternal (IE) pada Tabel 11 di atas menunjukkan bahwa objek wisata Danau Linouw Tomohon berada pada sel Idengan skor 3.902atau strategi melalui integrasi horizontal yang dapat digambarkan sebagai "tumbuh dan berkembang". Hal ini merupakan strategi utama untuk mengembangkan objek wisata dengan cara membangun dan memperluas potensi wisata yang ada guna meningkatkan daya tarik wisata yang tinggi.

\section{Analisis SWOT}

Hasil penghitungan nilai IFAS dan EFAS diperoleh hasil dengan total IFAS adalah 3.902 dan EFAS adalah 3.495, setelah mengetahui kedua nilai tersebut maka dapat disusun diagram analisis SWOT untuk mengetahui posisi relatif objek wisata Danau Linouw Kota Tomohon pada kuadran pertama, kedua, ketiga atau kuadran ke empat. Penghitungan analisis SWOT adalah sebagai berikut:

a. Jumlah dari perkalian bobot dan rating pada opportunity dan threat diselisihkan untuk mendapat titik Y.
Opportunity
$: 2.759$
Threat
Titik Y
$: 0.736$
: Opportunity - Threat $=$ $2.759-0.736=2.023$

b. Jumlah dari perkalian bobot dan rating pada strength dan weakness diselisihkan untuk mendapatkan titik X.

$$
\begin{array}{ll}
\text { Strength } & : 3.025 \\
\text { Weakness } & : 0.877 \\
\text { Titik X } & : \text { Strength }- \text { Weakness }= \\
& 3.025-0.877=2.148
\end{array}
$$

Hasil penghitungan di atas dapat ditentukan bahwa posisi relatif objek wisata Danau Linouw berada pada titik koordinat $(2.023 ; 2.148)$ pada kuadran pertama yang menunjukkan bahwa objek wisata Danau Linouw Tomohon memiliki kekuatan dan peluang sehingga dapat memanfaatkan peluang yang ada dengan menggunakan kekuatan yang dimiliki. Strategi pengembangan yang sesuai dengan posisi objek wisata Danau Linouw Tomohon adalah strategi mendukung kebijakan pada pertumbuhan wisata dan selengkapnya dapat dilihat pada Gambar 1 diagram di bawah ini:

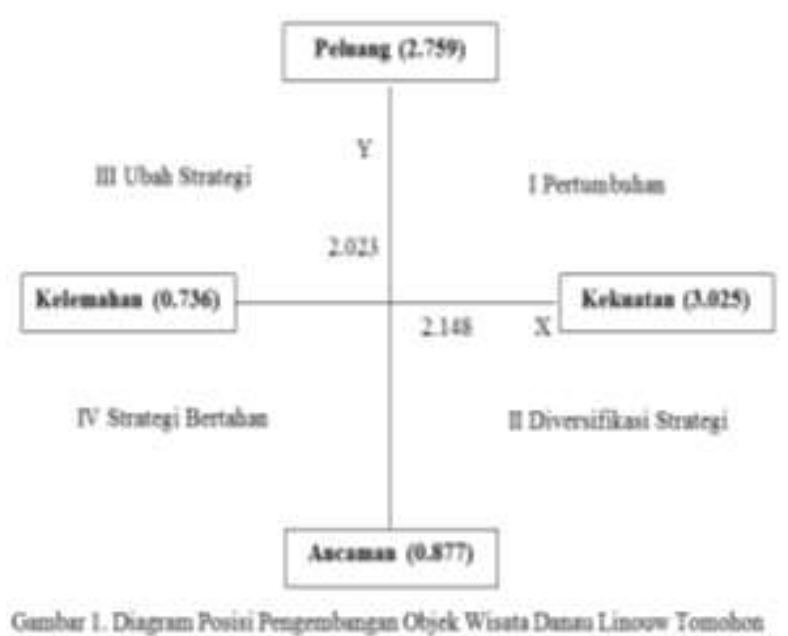

Berdasarkan hasil analisis pada Gambar 1 di atas bahwa strategi pengembangan objek wisata Danau Linouw Tomohon terletak pada posisi kuadran I atau terletak antara peluang eksternal dan kekuatan internal (strategi pertumbuhan) yaitu strategi yang didesain untuk mencapai pertumbuhan jumlah kunjungan wisatawan (frekuensi kunjungan dan asal daerah wisatawan), aset (obyek dan daya tarik wisata, prasarana dan sarana pendukung), pendapatan (retribusi masuk dan jumlah yang dibelanjakan). Posisi kuadran I tersebut menunjukkan posisi yang sangat menguntungkan karena obyek wisata Danau Linouw memiliki peluang dan kekuatan sehingga dapat memanfaatkan peluang yang ada. Strategi yang harus diterapkan dalam kondisi ini adalah strategi mendukung kebijakan pertumbuhan.

Selanjutnya menggunakan matriks untuk memperlihatkan strategi-strategi yang dapat dilakukan untuk pengembangan obyek wisata Danau Linouw. Strategi-strategi tersebut dimasukkan dalam Matriks Analisis SWOT. Matriks SWOT adalah matriks yang menginteraksikan faktor strategis internal dan eksternal. Matrik ini dapat menggambarkan secara jelas bagaimana peluang dan ancaman (eksternal) yang dihadapi dapat disesuaikan dengan kekuatan dan kelemahan yang dimiliki. Matrik SWOT selanjutnya dapat disajikan pada Tabel 12 berikut ini. 
Tabel 12. Matriks SWOT Pengembangan Objek Wisata Danau Linouw Tomohon

\begin{tabular}{lll}
\multicolumn{3}{c}{ Danau Linouw Tomohon } \\
\hline EEKUATAN (S) & KELEMAHAN (W) \\
\hline PELUANG (O) & SO & WO \\
\hline ANCAMAN (T) & ST & WT \\
\hline Sumber: Hasil Analisis SWOT 2015 & \\
\hline
\end{tabular}

\section{Strategi Pengembangan Objek Wisata Danau Linouw Tomohon}

Berdasarkan hasil analisis matriks SWOT pada Tabel 13 dapat dijabarkan beberapa strategi dasar untuk pengembangan obyek wisata Danau Linouw Tomohon dan secara umum dapat dirumuskan sebagai berikut.

\begin{tabular}{|c|c|c|}
\hline EFAS & $\begin{array}{l}\text { Kekuatan (Strength) } \\
\text { 1. Keindahan objek wisata } \\
\text { 2. Kesejukan di area objek } \\
\text { wisata } \\
\text { 3. Keramahan pelayan dan } \\
\text { masyarakat selitar } \\
\text { 4. Kebersihan diobjek } \\
\text { wisata } \\
\text { 5. Keamanan dilokasi objek } \\
\text { wisata } \\
\text { 6. Lokasi yang mudah } \\
\text { diakses }\end{array}$ & $\begin{array}{l}\text { Kelemahan (Weakness) } \\
\text { 1. Tidak adanya atraksi } \\
\text { wissta } \\
\text { 2. Minimnya pemasaran } \\
\text { objek wis ata } \\
\text { 3. Kurangnya } \\
\text { ketersediagn penjualan } \\
\text { marchendise } \\
\text { 4. Prasarana jalan yang } \\
\text { sempit } \\
\text { 5. Kurangnampaknya } \\
\text { 6. Ketugas keamanan } \\
\text { 6uliner kurang variatif }\end{array}$ \\
\hline Peluang (Opportunities) & StrategiSO & Strategi wo \\
\hline $\begin{array}{l}\text { Kebijakan pemerintah } \\
\text { daerah dan pusas yang } \\
\text { mendukung dalam } \\
\text { mengembangkan } \\
\text { pariwisata } \\
\text { 2. Diseminasi informasi } \\
\text { dengan kemajuan } \\
\text { teknologi } \\
\text { 3. Membentuk citra positif } \\
\text { bagi wisatawan lain } \\
\text { 4. Memberikan pendapatan } \\
\text { bagi daerah } \\
\text { 5. Minat masyarakat } \\
\text { terhadap pariwisata } \\
\text { 6. Terbukanya lapangan } \\
\text { kerja bagi masyarakat } \\
\text { sekitar }\end{array}$ & 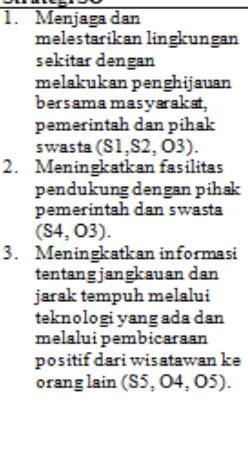 & $\begin{array}{l}\text { M. Mengembangkan } \\
\text { atraksi wisata di sektor } \\
\text { pariwisata dan } \\
\text { melakukan promosi } \\
\text { yang } \\
\text { berkesinambungan } \\
\text { melalui teknologi yang } \\
\text { ada (W1, W2, O1, O4). } \\
\text { 2. Memaksimalkan toko } \\
\text { souvenir melalui } \\
\text { masyarakat sekitar } \\
\text { untuk menigkatkan } \\
\text { pendapatan (W3, O2). } \\
\text { 3. Melakukan pelebaran } \\
\text { jalan oleh pihak } \\
\text { pemerintah dan swasta } \\
\text { (W5, O3). } \\
\text { 4. Mengurangi tarifmasulk } \\
\text { untuk meingkatkan } \\
\text { kunjungan wisata (W6, } \\
\text { O). }\end{array}$ \\
\hline Ancaman (Threats) & StrategiST & Strategi WT \\
\hline $\begin{array}{l}\text { 1. Adanya gunung merapi } \\
\text { aktif di sekitar obyek } \\
\text { wisata } \\
\text { 2. Efek bau belerang dari } \\
\text { objek wisata } \\
\text { 3. Ketertiban Lalu lintas } \\
\text { menuju objek wisata } \\
\text { 4. Berdekstannya objek } \\
\text { wisata dengan kawasan } \\
\text { pemukiman atau rumah } \\
\text { penduduk }\end{array}$ & $\begin{array}{l}\text { Berussha memelihara dan } \\
\text { melestarikan keragaman } \\
\text { alam (S1, S2, T1, T2). }\end{array}$ & $\begin{array}{l}\text {-Meningkatkan promosi } \\
\text { dan fasilitas pendukungan } \\
\text { (W2, W4, T1). } \\
\text { - Menambah Atraksi wisata. } \\
\text { - Menyediakan jalur } \\
\text { evalkusi i jika terjadi } \\
\text { bencana }\end{array}$ \\
\hline
\end{tabular}

\section{Strategi Pengembangan Obyek Wisata Danau Linouw Dalam Meningkatkan Pendapatan Asli Daerah (PAD) Pemerintah Kota Tomohon}

Berdasarkan hasil analisis Matriks SWOT, dapat uraikan beberapa strategi dasar dalam rangka pengembangan obyek wisata Danau Linouw Tomohon sebagai berikut:

a. Menjaga dan melestarikan lingkungan sekitar dengan melakukan penghijauan bersama masyarakat, pemerintah dan pihak swasta $(\mathrm{S} 1, \mathrm{~S} 2$, O3). Strategi ini terkait dengan pemandangan alam yang indah dan sejuk yang ada di sekitar obyek wisata Danau Linouw, sehingga perlu di kembangkan terus melalui penghijauan dan reboisasi sesuai dengan kaidah konservasi yang ada agar lingkungan fisik sekitar tetap hijau yang menghasilkan udara sejuk serta pemandangan alam yang indah dan asri.

b. Meningkatkan fasilitas pendukung dengan pihak pemerintah dan swasta (S4, O3). Strategi ini terkait dengan paket wisata dan fasilitas pendukung yang ada di obyek wisata Danau Linouw Tomohon dan strategi pengembangan yang harus dilakukan yaitu membangun tempat penginapan dan beberapa paket wisata yang dibutuhkan oleh wisatawan.Pengembangan fasilitas pendukung yang dimaksud yaitu bekerjasama dengan pihak pemerintah dan swasta yang berkepentingan di obyek wisata Danau Linouw Tomohon.

c. Meningkatkan informasi tentang jangkauan dan jarak tempuh melalui teknologi yang ada dan melalui pembicaraan positif dari wisatawan ke orang lain (S5, O4, O5). Strategi ini terkait dengan jarak tempuh yang mudah dijangkau dari pusat Kota Manado sebagai Ibu Kota Provinsi Sulawesi Utara maupun dari Kota Tomohon serta kota-kota lainnya yang ada di Kabupaten Minahasa. Hal ini tentunya memberikan kemudahan untuk lebih banyak wisatawan yang berkunjung di obyek wisata Danau Linouw, sehingga perlu meningkatkan informasi melalui teknologi yang ada dan melalui informasi positif yang diberikan wisatawan kepada orang lain yang ingin dan akan berkunjung ke obyek wisata Danau Linouw Tomohon.

d. Mengembangkan atraksi wisata di sekto pariwisata dan melakukan promosi yang berkesinambungan melalui teknologi yang ada (W1, W2, O1, O4). Kurangnya atraksi wisata dan promosi yang belum maksimal mengakibatkan menurunnya jumlah pengunjung yang berwisata di obyek wisata Danau Linouw sehingga perlu meningkatkan atraksi wisata dan melakukan promosi yang berkesinambungan melalui teknologi informasi ke berbagai daerah bahkan sampai luar negeri untuk menigkatkan jumlah kunjungan yang datang di obyek wisata Danau Linouw Tomohon.

e. Memaksimalkan toko souvenir melalui masyarakat sekitar untuk menigkatkan pendapatan (W3, O2). Toko Souvenir di obyek wisata Danau Linouw belum ada sehingga perlu mengembangkan toko souvenir melalui hasil kerajinan atau keterampilan dari warga lokal untuk meningkatkan pendapatan masyarakat, namun juga memberik kesan tersendiri terhadap wisatawan yang datang berkunjung agar hal tersebut menjadi bagian dari daya tarik wisata bagi wisatawan selanjutnya. 
f. Melakukan pelebaran jalan oleh pihak pemerintah dan swasta (W5, O3). Kondisi jalan masuk yang sempit yaitu mulai dari jalan utama menuju ke obyek wisata Danau Linouw sehingga perlu melakukan pelebaran dan pengaspalan jalan agar mempermudah arus masuk dan keluar bagi wisatawan yang berkunjung. Kondisi jalan yang baik tentunyan memberikan nilai positif bagi masyarakat sekitar maupun wisatawan yang datang sehingga diperlukan kerjasama antara pemerintah dan pihak swasta dalam hal ini pengusah industri pariwisata yang ada di obyek wisata Danau Linouw.

g. Mengurangi harga wisata untuk meingkatkan kunjungan wisata (W6, O). Strategi ini dilakukan untuk menekan harga wisata yang relatif mahal yaitu sekitar Rp. 25.000, dan retribusi dari pemerintah Kota Tomohon sebesar Rp. 5.000, sehingga jumlah keseluruhan adalah Rp. 30.000 per orang. Harga wisata yang mahal tersebut bisa menimbulkan jumlah pengunjung yang mau berwisata di Danau Linouw berkurang karena faktor biaya yang relatif mahal sehingga perlu melakukan evaluasi dari pihak pengelola obyek wisata Danau Linouw.

h. Berusaha memelihara dan melestarikan keragaman alam (S1, S2, T1, T2). Strategi ini terkait dengan fenomena alam yang bisa terjadi di obyek wisata sehingga terus bertahan dan berusaha memelihara dan melestarikan lingkungan sekitar dengan melakukan penghijauan atau reboisasi yang berkelanjutan agar tidak terjadi erosi dan sedimentasi yang mengakibatkan terjadinya pendangkalan danau.

i. Meningkatkan promosi dan fasilitas pendukungan (W2, W4, T1). Strategi pengembangan yang harus dilakukan melalui promosi yang maksimal kepada para wisatawan maupun masyarakat secara umum baik ditingkat regional maupun mancanegara agar tetap menjadi salah satu alternatif kunjungan wisata di Sulawesi Utara sehingga perlu mengembangkan fasilitas pendukung yang dibutuhkan oleh para wisatawan.

Hasil uraian di atas menunjukkan bahwa obyek wisata Danau Linouw Tomohon berada pada posisi yang kuat dan berpeluang. Rekomendasi strategi yang diberikan adalah progresif, artinya obyek wisata Danau Linouw Tomohon dalam kondisi prima dan mantap sehingga sangat dimungkinkan untuk terus melakukan perluasan, memperbesar pertumbuhan dan meraih kemajuan secara maksimal.

\section{Pembahasan}

Obyek wisata Danau Linouwsecara internal memiliki kekuatan untuk menarik kunjungan wisatawan baik mancanegara maupun lokal. Kekuatan tersebut dapat terlihat pada keindahan obyek wisata yang dapat dinikmati oleh pengunjung, kesejukan alami yang dimiliki, keramahan yang diberikan oleh pelayan dan masyarakat sekitar, kebersihan disekitar obyek wisata, kenyamanan yang dirasakan selama berada di obyek wisata, serta kemudahan dalam mengakses lokasi wisata.

Meskipun secara internalobyek wisata danau Linouw memiliki kekuatan yang dapat menarik kunjungan wisatawan, namun masih terdapat pula Kelemahan yang perlu dibenahi. Kelemahankelemahan yang perlu dibenahi di antaranya: masih kurangnya atraksi wisata yang diberikan bagi pengunjung, minimnya pemasaran obyek wisata yang dilakukan dengan memanfaatkan kemajuan teknologi informasi, kurangnya ketersediaan penjualan marcendise, kurang nampaknya petugas keamanan di lokasi area obyek wisata, kuliner yang kurang variatif bagi pengunjung serta prasarana jalan yang sempit untuk masuk ke dalam lokasi obyek wisata.

Secara eksternal, pada dasarnya obyek wisata Danau Linouw memiliki peluangdalam hal pengembangan dan pengelolaan untuk meningkatkan PAD Kota Tomohon. Dengan adanya kebijakan pemerintah daerah dan pusat yang berkomitmen untuk mengembangkan obyek-obyek wisata di setiap daerah yang ada merupakan sebuah peluang bagi pengelola obyek wisata Danau Linouw maupun pemerintah daerah Kota Tomohon untuk meningkatkan penghasilan serta pendapatannya. Apalagi minat masyarakat terhadap dunia pariwisata sedang tinggi. Semakin majunya sebuah obyek wisata setidaknya $n$ membuka peluang lapangan kerja bagi masyarakat sekitar.

Meskipun demikian, terdapat beberapa hal yang perlu diantisipasi oleh pengelola obyek wisata maupun pemerintah daerah terhadap ancaman yang dapat mengganggu wisatawan dalam mengunjungi obyek wisata Danau Linouw. Ancaman tersebut dapat berupa efek bau belerang yang berasal dari danau, yang apabila tidak diberikan batasan bagi pengunjung dapat memberikan ancaman keselamatan bagi pengunjung. Selain itu, obyek wisata Danau Linouw yang berada dekat dengan gunung merapi yang sewaktu-waktu dapat erupsi tentunya mengganggu siklus kunjungan. Ancaman lainnya ialah berdekatannya obyek wisata Danau Linouw dengan obyek wisata yang ada di daerah sekitar menjadi ancaman keberlangsungan obyek wisata dalam hal persaingan jumlah pengunjung.

Terdapat empat objek wisata yang bisa kita kunjungi di Danau Linouw yaitu D'Linow café, dengan biaya karcis masuk 25.000/pax, Liberty biaya karcis masuk 10.000/pax, Green Lake biaya masuk 10.000/pax dan Pordakwis atau kelompok sadar wisata yang tidak di kenakan biaya masuk karena tempat ini milik pemerintah dan di kelolah oleh kelompok sadar wisata yang berada di daerah lahendong. 
Dengan semakin banyaknya objek - objek wisata yang ada di sekitarDanau Linouw maka jumlah wisatawan baik mancanegara maupun lokal semakin bertambah ini terlihat dari data kunjungan dinas pariwisata kota Tomohon selama lima tahun terakhir yaitu tahun 2013 jumlah wisatawan mancanegara 4584 lokal 14031, tahun 2014 jumlah wisatawan mancanegara 7542 dan lokal 36938,tahun 2015 jumlah wisatawan mancanegara 4262 dan lokal 62468, tahun 2016 jumlah wisatawan mancanegara 14882 lokal 69888, tahun 2017 jumlah wisatawan mancanegara 70429 lokal 127545.

Semakin baik pengembangan dan pengelolaan obyek wisata Danau Linouw yang ada, maka semakin banyak pula jumlah wisatawan yang datang mengunjungi obyek wisata tersebut. Dengan demikian, semakin banyak jumlah wisatawan yang datang mengunjungi Danau Linouw maka semakin meningkat pula Pendapatan Asli Daerah Kota Tomohon yang diperoleh melalui retribusi masuk.

Berdasarkan data Pandapatan Asli Daerah (PAD) bersumber dari retribusi jumlah Tahun $2015 \mathrm{Rp}$. 216. 880.000 tahun 2016 Rp. 142.465 .000 dan tahun 2017 Rp. 286.640.000, pada tahun 2015 ke tahun 2016 mengalami penurunan bukan Karena jumlah pengunjung yang berkurang tetapi disebabkan adanya temuan dari kejaksaan RI kota Tomohon bahwa ada beberapa objek wisata Danau Linouw belum memiliki izin sehingga retribusi dihentikan selama empat bulan dan sekarang sudah bisa beroperasi lagi karena sudah memilik izin, sehingga pada tahun 2017 mengalami kenaikan sampai sekarang.

Pariwisata telah menjadi sebuah industri pada saat ini. Wahab (1975) mengemukakan bahwa industri pariwisatamerupakan salah satu jenis industri baru yang mampu menghasilkan pertumbuhan ekonomi yang cepat dalam penyediaan lapangan kerja, peningkatan penghasilan, standar hidup serta menstimulasi sektor-sektor produktivitas lainnya. Selanjutnya, sebagai sektor yang kompleks, juga meliputi indsutri-industri klasik yang sebenarnya seperti industri kerajinan tangan dan cenderamata, di mana penginapan dan transportasi juga dipandang sebagai industri.

Pengembangan pariwisata merupakan segala kegiatan dan usaha yang terkoordinasi untuk menarik wisatawan, menyediakan semua prasarana dan sarana, barang dan jasa fasilitas yang diperlukan, guna melayani kebutuhan wisatawan. Segala kegiatan dan pengembangan pariwisata mencakup segi-segi yang amat luas dan menyangkut berbagai segi kehidupan dalam masyarakat, mulai dari kegiatan angkutan, akomodasi, atraksi wisata, makanan dan minuman, cenderamata, pelayanan dan suasana kenyamanan.

Pembangunan pariwisata merupakan kegiatan usaha yang terkoordinasi untuk menarik wisatawan, menyediakan semua prasarana dan sarana untuk melayani kebutuhan wisatawan. Kegiatan pengembangan pariwisata tersebut mencakup segi-segi yang amat luas dan menyangkut berbagai segi kehidupan dalam masyarakat, sedangkan manfaat pengembangan pariwisata (Musanef, 1996), yaitu:

1. Memperluas kesempatan usaha

2. Memperluas lapangan kerja

3. Meningkatkan pendapatan masyarakat dan pemerintah

4. Mendorong pelestarian budaya, peninggalan sejarah serta lingkungan hidup

5. Mendorong sektor terkait untuk lebih berkembang

6. Mendorong terpeliharanya ketertiban dan keamanan

7. Memperkokoh persatuan dan kesatuan bangsa

8. Memperluas wawasan nusantara dan menumbuhkan rasa cinta tanah air

Pariwisata sebagai suatu kegiatan lintas sektoral memerlukan koordinasi derajat tinggi. Pengembangan pariwisata tidak hanya membenahi obyek wisata alam atau budaya, atau hanya melakukan pengembangan akomodasi dan restoran, tetapi jauh lebih luas dari itu. Wisatawan yang datang tetap memerlukan fasilitas dasar, angkutan, akomodasi, makanan, minuman, atraksi wisata, pelayanan, cenderamata, suasana aman dan lain-lain. Dampak pengembangan pariwisata merupakan dampak berganda. Pariwisata yang sangat luas menjadi pendorong terhadap pengembangan pertanian, peternakan, kehutanan, perindustrian sehingga perlu diadakan sinkronisasi program dalam kaitan aspek pemerataan pembangunan (Musanef, 1996).

Peran masyarakat dalam upaya pengembangan pariwisata sangat penting dalam arti yang seluasluasnya. Karena penyelenggaraan kepariwisataan diarahkan demi terwujudnya pemerataan pendapatan dan pemerataan kesempatan berusaha, maka pelaksanaan berbagai usaha pariwisata yang dilakukan dapat saling mengisi, saling berkaitan dan saling menunjang satu dengan lainnya (Musanef, 1996).

Kesadaran masyarakat perlu ditumbuh kembangkan guna membangun sebuah industri wisata. Partisipasi dan dukungan segenap masyarakat merupakan faktor utama untuk mewujudkan iklim yang kondusif bagi berkembangnya kepariwisataan di suatu destinasi wisata. Kesadaran masyarakat yang tinggi akan pariwisata pada gilirannya dapat meningkatkan jumlah kunjungan wisatawan yang nantinya akan bermuara pada upaya peningkatan pada masyarakat lokal. Bukan hanya masyarakat lokal saja, dengan berjalannya industri wisata di suatu daerah secara otomatis akan menambah pendapatan bagi pemerintah daerah setempat.

Peningkatan kesadaran masyarakat dalam menumbuh kembangkan industri pariwisata dapat dijalankan dengan menggunakan konsep Sapta Pesona. Sebagaimana Peraturan Menteri Kebudayaan dan Pariwisata Nomor: PM.04/UM.001/MKP.2008, Sapta Pesona merupakan sebuah konsep dalam rangka 
meningkatkan kinerja pembangunan pariwisata nasional dengan mengoptimalkan dukungan, peran serta partisipasi masyarakat melalui kegiatan Sadar Wisata yang bertujuan untuk meningkatkan pemahaman segenap komponen masyarakat tentang pariwisata, dalam mewujudkan iklim yang kondusif bagi tumbuh dan berkembangnya kepariwisataan di suatu wilayah (Anonimous, 2009).

Dalam Panduan Sadar Wisata Untuk Masyarakat Umum, Direktorat Jendral Pariwisata, Seni dan Budaya (1998) menyebutkan bahwa Sapta Pesona terdiri dari tujuh unsur, yaitu: aman, tertib, bersih, sejuk, indah, ramah tamah, dan kenangan. Aman diartikan bahwa wisatawan akan senang berkunjung ke suatu tempat apabila merasa aman, tentram, tidak takut, terlindung dan bebas dari tindak kejahatan, kekerasan ancaman, seperti pencopetan, pemerasan, penodongan dan penipuan.

Kondisi tertib diartikan sebagai sebuah kondisi yang sangat didambakan oleh setiap orang termasuk wisatawan. Kondisi tersebut tercermin dari suasana yang teratur, rapi dan lancar serta menunjukkan disiplin yang tinggi dalam semua segi kehidupan masyarakat seperti lalu lintas tertib, teratur dan lancar, alat angkutan datan berangkat tepat pada waktunya. Tidak tampak orang yang berdesakan atau berebut untuk mendapatkan atau membeli sesuatu yang diperlukan. Selain itu, bangunan dan lingkungan ditata teratur rapi dan informasi yang diberikan haruslah benar dan tidak membingungkan.

Bersihan merupakan suatu keadaan atau kondisi lingkungan yang menampilkan suasana bebas dari sampah, limbah, penyakit dan pencemaran. Wisatawan merasa betah dan nyaman bila berada di tempat-tempat yang bersih dan sehat. Lingkungan yang bersih baik di rumah sendiri maupun di tempat-tempat umum, seperti di hotel, restaurant, angkutan umum, tempat rekreasi, tempat buang air kecil/besar, dan lain-lain. Sajian makanan dan minuman bersih dan sehat. Penggunaan dan penyediaan alat perlengkapan yang bersih seperti sendok, piring, tempat tidur, alat olah raga dan lainlain. Pakaian dan penampilan petugas juga harus bersih rapi dan tidak mengeluarkan bau tidak sedap.

\section{KESIMPULAN DAN SARAN}

\section{Kesimpulan}

Hasil dan pembahasan yang telah diuraikan diatas, dapat disimpulkan bahwa strategi pengembangan Obyek Wisata Danau Linouw dalam meningkatkan Pendapatan Asli Daerah (PAD) Kota Tomohon berdasarkan hasil analisis SWOT yang telah dilakukan, terletak pada posisi Kuadran I atau strategi melalui Integrasi Horizontal, yang terletak antara peluang eksternal dan kekuatan internal. Hal ini merupakan strategi utama untuk mengembangkan obyek wisata dengan caramempertahankan kekuatan dan mengoptimalkan peluang sambil memperbaiki kelemahan dan mengantisipasi ancaman yang ada dalam upaya meningkatkan jumlah kunjungan wisatawan yang dapat meningkatkan Pendapatan Asli Daerah (PAD) Kota Tomohon.

\section{Saran}

berikut:

Adapun saran dalam penelitian ini, sebagai

1. Untuk meningkatkan Pendapatan Asli Daerah Kota Tomohon, maka diharapkan Pemerintah dan Swasta khususnya pengelola Obyek Wisata Danau Linouw perlu merencanakan sebuah strategi pemasaran agar wisatawan yang berkunjung akan terus bertambah.

2. Memperbaiki sarana dan prasarana terkait jalan akses menuju obyek wisata Danau Linouw yang dinilai kurang luas untuk dilewati pengunjung yang menggunakan kendaraan bermotor.

3. Untuk memberikan kenangan berupa kesan yang positif maka diperlukan cenderamata yang merupakan khas dari Kota Tomohon untuk di bawa pulang oleh wisatawan sebagai kenangkenangan.

\section{DAFTAR PUSTAKA}

Adisasmita, Rahardjo. 2010. Pembangunan Pedesaan dan Perkotaan. Yogyakarta: Graha Ilmu.

Fandeli, Chafid dan Mukhlisom. 2000. Pengusahaan Ekowisata.Yogyakarta: Fakultas Kehutanan Universitas Gadjah Mada

Freddy, Rangkuti. 2006. Teknik Mengukur dan Strategi Meningkatkan Kepuasan Pelanggan. Jakarta : Penerbit PT Gramedia Pustaka Utama.

Nurhadi Febrianti Dwi Cahya, Mardiyono, Stefanus Pani Rengu. 2013. Strategi Pengembangan Pariwisata Oleh Pemerintah Daerah Terhadap Pendapatan Asli Daerah (Studi pada Dinas Pemuda, Olahraga, Kebudayaan dan Pariwisata Kabupaten Mojokero)Jurnal Administrasi Publik (JAP), Vol. 2, No. 2, Hal. 325-331

Pitana dan Diarta. 2009. Pengantar Ilmu Pariwisata. Andi.Yogyakarta

Tarigan, R. 2006. Ekonomi Regional: Teori dan Aplikasi (Edisi Revisi). Bumi Aksara. Jakarta.

Todaro, 2000. Pembangunan Ekonomi di Dunia Ketiga. Jilid I, Edisi Keenam. Jakarta : Erlangga

Undang-Undang Nomor 32 Tahun 2004 tentang Pemerintahan Daerah

Undang-Undang Nomor 10 Tahun 2009 tentang Kepariwisataan

Undang-Undang Nomor 26 Tahun 2007 tentang Penataan Ruang. Departemen Pekerjaan Umum. Direktorat Jendral Penataan Ruang. Jakarta.

Undang-Undang Nomor 23 Tahun 2014 tentang Pendapatan Asli Daerah- 